\title{
Experimental Studies Regarding the Distribution of the Masticatory Pressures According to the Turn's Length of the Dental Implants
}

\author{
ALEXANDRU DANIEL REFERENDARU ${ }^{1}$, ANCA IULIANA POPESCU², IASMIN MIREA ${ }^{1}$, \\ STEFANIA ANDRADA IANCU ${ }^{1}$, RALUCA MONICA COMANEANU ${ }^{2 *}$, \\ HORIA MIHAIL BARBU ${ }^{2}$ \\ ${ }^{1}$ Titu Maiorescu Doctoral School of Dental Medicine, 22 Dambovnicului Str., 040441, Bucharest, Romania \\ ${ }^{2}$ Titu Maiorescu University of Bucharest, Faculty of Dental Medicine, 67A Gh. Petrascu Str., 031593, Bucharest, Romania
}

\begin{abstract}
In order to study comparatively the behaviour of the bone-implant interface at mechanical stresses depending on the length of the implant turns, we chose a complex case, a total bimaxillary edentate. 7 implants were virtually inserted into the maxilla (2 pterigoid implants in the lateral regions and 3 implants in the frontal region), and 4 implants were inserted into the mandible (two in the premolar regions and two corresponding to the canines). The FEA analyzes were performed separately for the maxilla and for the mandible, applying a force of $200 \mathrm{~N}$ on each type of implant. The critical areas, in which the extreme values of the strains develop, are located into the bone on the neck-implant level, and its apex level, regardless of the type of implant and regardless of the maxillary or mandibular area where the implants were virtually inserted. Implants with small turns induce lower stresses and deformations, compared to implants with large turns.
\end{abstract}

Keywords: FEA, dental implants, short turns, long turns

\section{Introduction}

The rehabilitation of the edentulous jaws with the help of dental implants is now considered a safe therapeutic possibility [1], which can offer patients the restoration of the structures of the dentalmaxillary apparatus from an aesthetic and functional point of view. The use of a fixed prosthetic superstructure, aggregated by screwing or a movable over-prosthesis applied over a conjunction bar can be considered treatment variants for an edentulous patient with marked maxillary bone atrophy. [2, 3] In the case of a fixed prosthetic superstructure aggregated by screwing, the fracture of the prosthetic restoration or the fracture of one of the fixing screws may occur, followed by a peri-implantar bone loss, associated with the inflammation of the soft and hard tissues around the implant $[4,5]$.

Finite element analysis is an currently experimental method used more and more frequently in the field of dental medicine [6-21] to estimate the behaviour of biomaterials and human tissues. The use of engineering expertise in dentistry has partly helped to understand the biomechanical aspects related to the osseointegration of the implants [1]. However, at the present moment, the mechanisms responsible for the lack of implant integration, the therapeutic failure or the fracture of the components, are not yet fully known and the internationally reported data about the influence of some biomechanical parameters are not very conclusive [22], which justifies the further analysis of the different types of edentulous and implants for a better characterization and justification of the phenomena occurring at the bone-implant interface.

\section{Materials and methods}

In order to study comparatively the behavior of the bone-implant interface at mechanical stresses depending on the length of the implant turns, we chose a complex case, a total bimaxillary edentate. The patient's CBCT was imported into Mimics Innovation Suite 17, Materialise NV@ and processed. After processing, 7 implants were virtually inserted into the maxilla (2 pterigoid implants in the lateral regions and 3 implants in the frontal region), and 4 implants were inserted into the mandible (two in the premolar 
regions and two corresponding to the canines) (Figure 1). Within the study, the 3 implants inserted into the frontal maxillar region and the 4 mandibular implants were considered initially with large turns, subsequent with small turns, in order to detect possible differences in the bone-implant interface depending on the implant design, respectively the size of their turns.

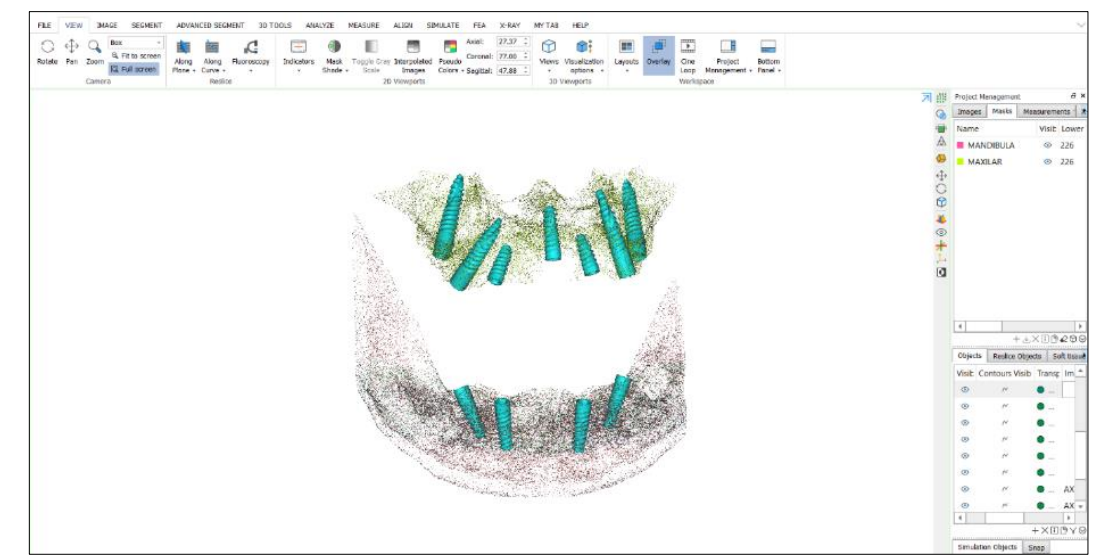

Figure 1. The positions where the implants were virtually inserted

Mastication stress simulations were performed with ANSYS 16, ANSYS Inc $\odot$. The analyzes were performed separately for the maxilla and for the mandible, applying a force of $200 \mathrm{~N}$ on each type of implant. Considering the particular situation of the patient, with advanced bone resorption and with increased porosity of the residual ridges, higher values of the mastication force were not discussed. The properties of the materials used in the simulations are presented in Table 1.

Table 1. The TiAlV alloy, mandibular bone and maxillary bone used in simulations

\begin{tabular}{|c|c|c|c|c|}
\hline & Young's Modulus MPa & Poisson's Ratio & Bulk Modulus MPa & Shear Modulus MPa \\
\hline TiAlV alloy & $1 . \mathrm{e}+005$ & 0.3 & 83333 & 38462 \\
\hline $\begin{array}{c}\text { Mandibular } \\
\text { bone }\end{array}$ & 8000 & 0.31 & 7017.5 & 3053.4 \\
\hline $\begin{array}{c}\text { Maxillary } \\
\text { bone }\end{array}$ & 2000 & 0.3 & 1666.7 & 769.23 \\
\hline
\end{tabular}

\section{Results and discussions}

After the calculations were performed, the results were analyzed and the value tables were obtained for each considered calculation element.

\section{A) Implants with large turns inserted at the mandibular level}

The equivalent pressure varied between a minimum of $9.8508 \mathrm{e}-9 \mathrm{MPa}$ and a maximum of 27.741MPa, with an average of 2.5309MPa (Figure 2a).

The equivalent elastic relative deformation ranged from $1.5423 \mathrm{e}-003 \mathrm{~mm} / \mathrm{mm}$ to $2.0501 \mathrm{e}-012$ $\mathrm{mm} / \mathrm{mm}$, with an average of $1.1757 \mathrm{e}-004 \mathrm{~mm} / \mathrm{mm}$ (Figure $2 \mathrm{~b}$ ).

The total deformation ranged from 0 , a value recorded at the level of the palatal arch and in the interincisive area, up to a maximum of $5.9288 \mathrm{e}-003 \mathrm{~mm}$ recorded in region 43 , with an average of 2.2436e-003mm (Figure 2c).

Normal pressure ranged from $-21.694 \mathrm{MPa}$ to $9.4 \mathrm{MPa}$, with an average of $-0.29378 \mathrm{MPa}$ (Figure $2 \mathrm{~d}$ ).

The shear stress on the XY axis ranged from -10.063MPa to $11.074 \mathrm{MPa}$. The average value of the shear stress was 2.6217e-002MPa (Figure 2e).

On the $\mathrm{YZ}$ axis, the shear stress varied between $-9.6772 \mathrm{MPa}$ and $8.7187 \mathrm{MPa}$ with an average of $1.2227 \mathrm{e}-002 \mathrm{MPa}$ (Figure 2f). On the $\mathrm{XZ}$ axis, the shear stress was between the limits $-10.063 \mathrm{MPa}$ and 11.074MPa with an average of $2.6217 \mathrm{e}-002 \mathrm{MPa}$ (Figure $2 \mathrm{~g}$ ). 
The deformation in the OX direction varied between $-3.3131 \mathrm{e}-003 \mathrm{~mm}$ and $1.2151 \mathrm{e}-003 \mathrm{~mm}$, with the average of $-1.555 \mathrm{e}-004 \mathrm{~mm}$ (Figure $2 \mathrm{~h}$ ). On the OY direction it ranged from $-1.62 \mathrm{e}-003 \mathrm{~mm}$ to $1.2504 \mathrm{e}-003 \mathrm{~mm}$, with an average of $3.2406 \mathrm{e}-004 \mathrm{~mm}$ (Figure $2 \mathrm{i}$ ). On the OZ direction it was between $5.7362 \mathrm{e}-003 \mathrm{~mm}$ and $4.5881 \mathrm{e}-004 \mathrm{~mm}$, and the average was $-1.9461 \mathrm{e}-003 \mathrm{~mm}$ (Figure $2 \mathrm{j}$ ).

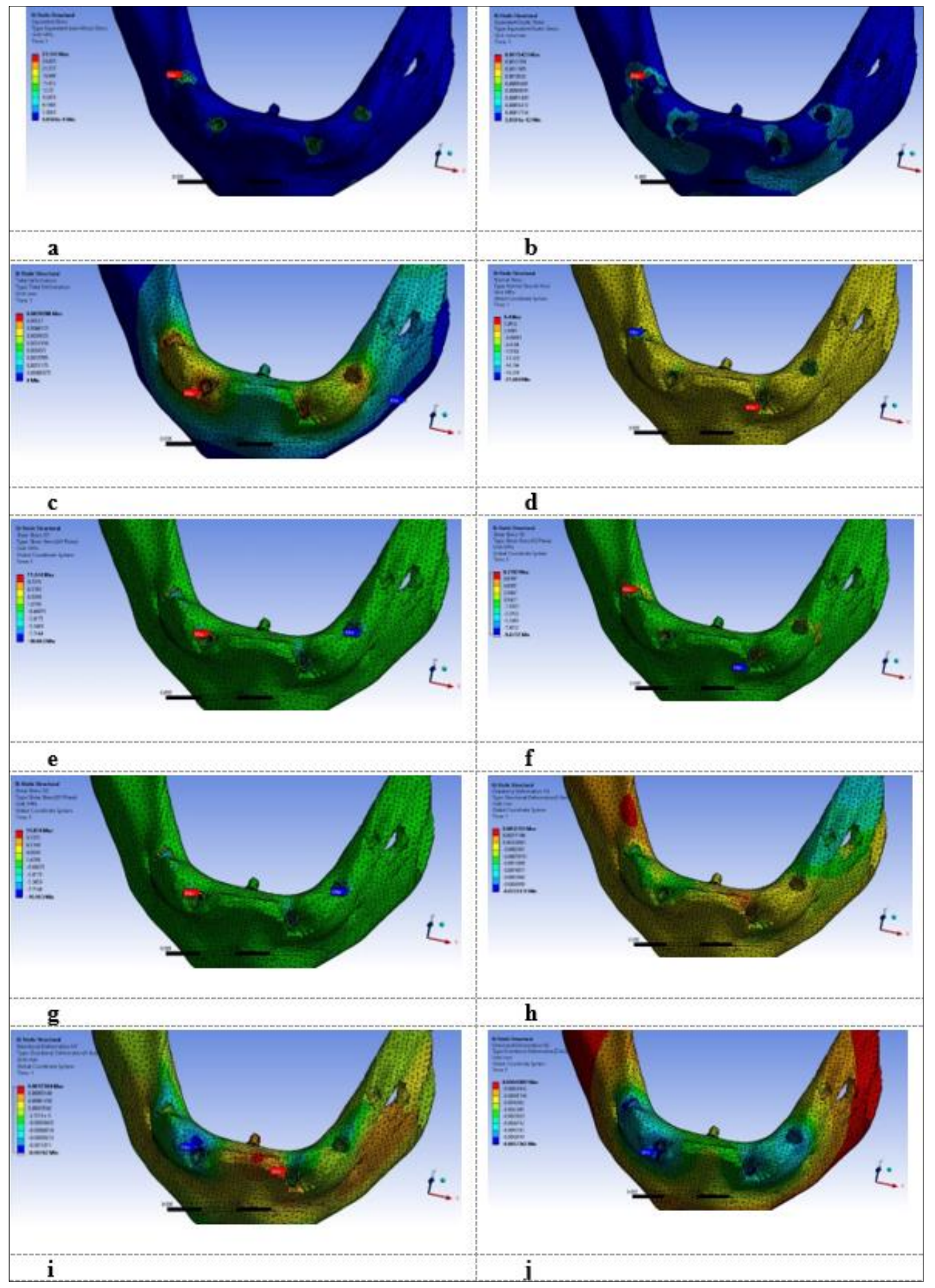

Figure 2, Simulations on the implants with large turns inserted at the mandibular level: a) Equivalent pressure; b) Equivalent elastic relative deformation; c) Total deformation; d) Normal pressure; e) Shear stress on the XY axis; f)- Shear stress on the YZ axis; g) Shear stress on the XZ axis; h) Deformation on the OX direction; i) Deformation on the OY direction; j) Deformation on the OZ direction 


\section{B) Implants with small turns inserted at the mandibular level}

The equivalent pressure varied between a minimum of $8.4749 \mathrm{e}-008 \mathrm{MPa}$ and a maximum of 44.207MPa, with an average of $8.1404 \mathrm{MPa}$ (Figure 3a).

The equivalent elastic relative deformation ranged from $1.2144 \mathrm{e}-011 \mathrm{~mm} / \mathrm{mm}$ to $1.3047 \mathrm{e}-003$ $\mathrm{mm} / \mathrm{mm}$, with an average of $1.3043 \mathrm{e}-004 \mathrm{~mm} / \mathrm{mm}$ (Figure $3 \mathrm{~b}$ ).

The total deformation ranged from $0 \mathrm{~mm}$, a value that was recorded at the mandibular basilar, up to a maximum of $8.9066 \mathrm{e}-003 \mathrm{~mm}$ that was recorded at the neck-implant region, with an average of $3.5525 \mathrm{e}-003 \mathrm{~mm}$ (Figure 3c).

Normal pressure varied between $-17.621 \mathrm{MPa}$ and $12.342 \mathrm{MPa}$, with an average of $-0.30859 \mathrm{MPa}$ (Figure 3d).

The shear stress on the XY axis ranged from $-10.108 \mathrm{MPa}$ to $10.709 \mathrm{MPa}$. The average value of the shear stress was 7.3699e-002MPa (Figure 3e). On the YZ axis, the shear stress varied between 13.958MPa and $13.205 \mathrm{MPa}$, with an average value of $0.33477 \mathrm{MPa}$ (figure $3 \mathrm{f}$ ). On the $\mathrm{XZ}$ axis, the shear stress was between the limits $-14.595 \mathrm{MPa}$ and $12.244 \mathrm{MPa}$, the average being $0.39396 \mathrm{MPa}$ (Figure $3 \mathrm{~g}$ ).

The deformation on the OX direction varied between $-3.5816 \mathrm{e}-003 \mathrm{~mm}$ and $2.9764 \mathrm{e}-003 \mathrm{~mm}$, with an average of $2.7145 \mathrm{e}-004 \mathrm{~mm}$ (Figure $3 \mathrm{~h}$ ). On the OY direction, the deformation varied between $5.1212 \mathrm{e}-003 \mathrm{~mm}$ and $7.8937 \mathrm{e}-004 \mathrm{~mm}$, the average being $-1.1834 \mathrm{e}-003 \mathrm{~mm}$ (Figure 3i). On the OZ direction, the deformation was between $-7.7482 \mathrm{e}-003 \mathrm{~mm}$ and $2.6033 \mathrm{e}-003 \mathrm{~mm}$, and the average was 2.9909e-003mm (Figure 3j).

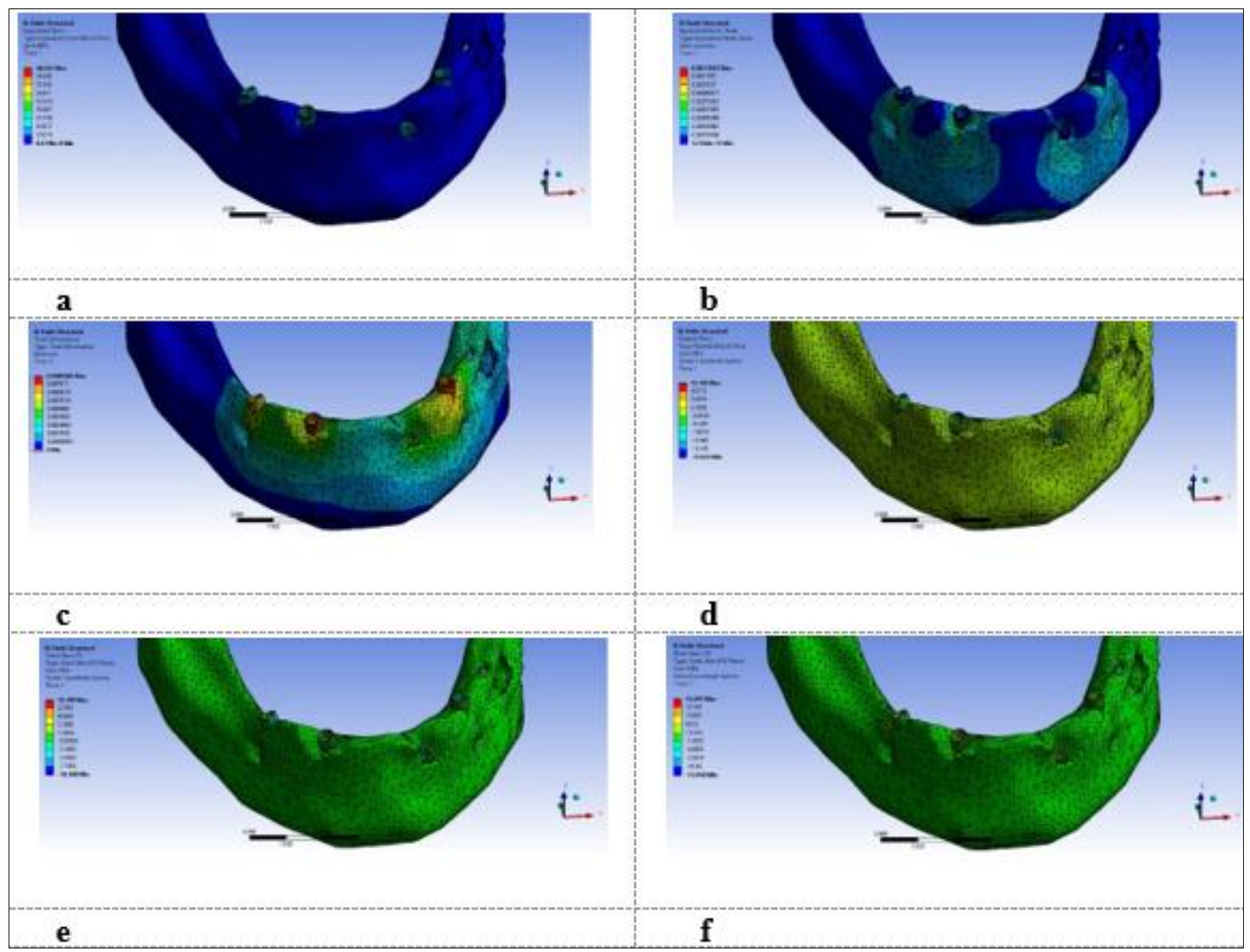

Figure 3. Simulations on the implants with small turns inserted at the mandibular level: a) Equivalent pressure; b) Equivalent elastic relative deformation; c) Total deformation; d) Normal pressure;

e) Shear stress on the XY axis; $f$ )- Shear stress on the YZ axis 


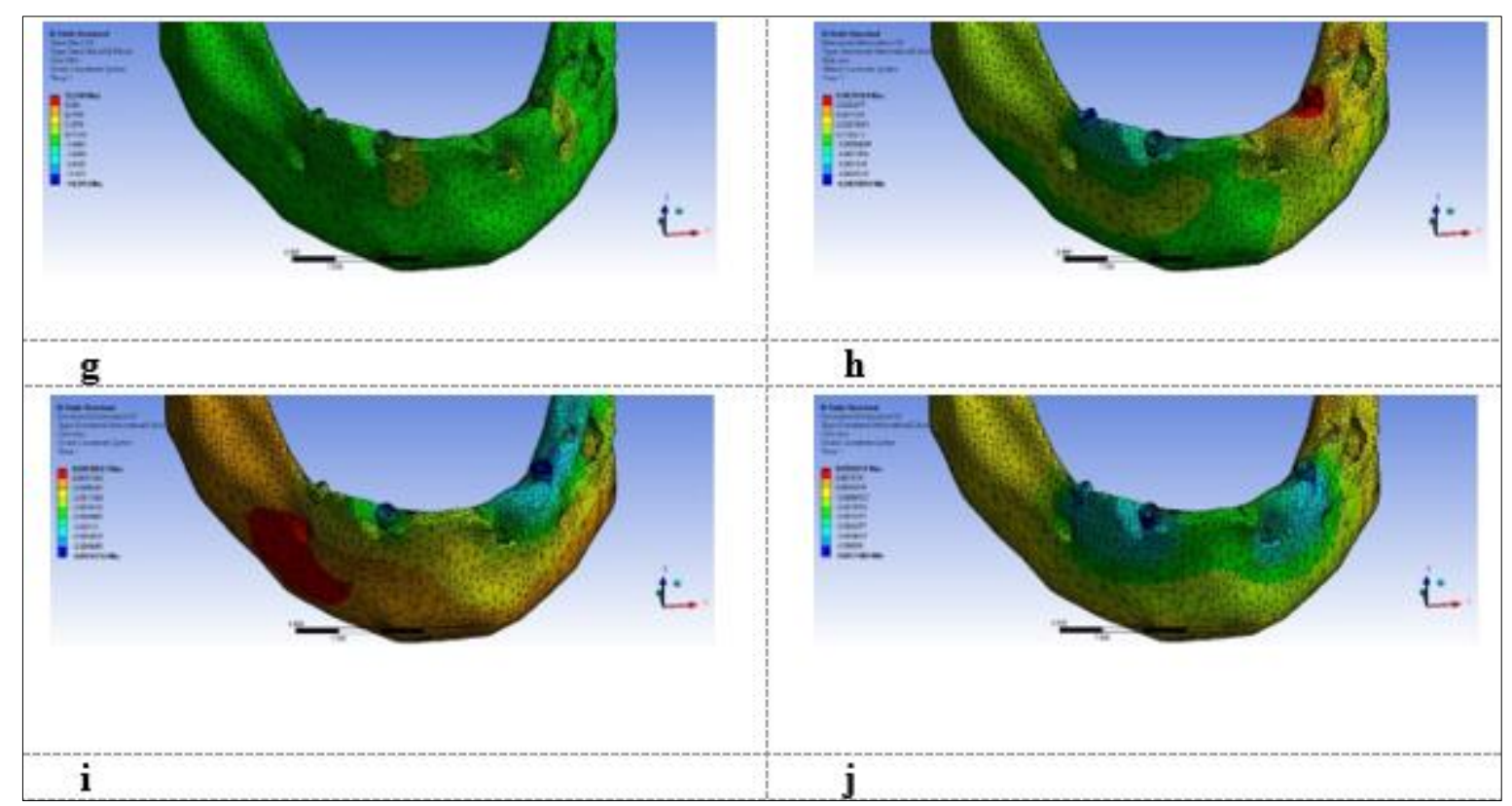

Figure 3. Simulations on the implants with small turns inserted at the mandibular level:

g) Shear stress on the XZ axis; h) Deformation on the OX direction; i) Deformation on the $\mathrm{OY}$ direction; j) Deformation on the OZ direction

\section{C) Implants with large turns inserted at the maxillary level}

The equivalent pressure (von-Mises) varied between a minimum of $0 \mathrm{MPa}$ and a maximum of 164.63MPa, with an average of $6.1385 \mathrm{MPa}$ (Figure $4 \mathrm{a}$ ). The minimum pressure was recorded in quadrant 1 , and the maximum pressure in quadrant 2.

The equivalent elastic relative deformation ranged from $0 \mathrm{~mm} / \mathrm{mm}$ to $2.3021 \mathrm{e}-002 \mathrm{~mm} / \mathrm{mm}$, with an average of $8.4697 \mathrm{e}-004 \mathrm{~mm} / \mathrm{mm}$ (Figure $4 \mathrm{~b}$ ).

The total deformation ranged from 0 , a value that was recorded at the alveolar ridge, up to a maximum of $7.9164 \mathrm{e}-002 \mathrm{~mm}$ that was recorded at the tuberosity region, with an average of $1.7599 \mathrm{e}-002 \mathrm{~mm}$ (Figure 4c).

Normal pressure varied between $-79.126 \mathrm{MPa}$ and $94.987 \mathrm{MPa}$, with an average of $-0.24352 \mathrm{MPa}$ (Figure 4d).

The shear stress on the XY axis ranged from -45.285MPa to 29.741MPa. The average value of the shear stress was $-5.2877 \mathrm{e}-002 \mathrm{MPa}$ (Figure 4e). The shear stress on the YZ axis varied between a minimum of $-35.4 \mathrm{MPa}$ and a maximum of $49.214 \mathrm{MPa}$, with an average of $-0.43694 \mathrm{MPa}$ (Figure $4 \mathrm{f}$ ). The shear stress on the $\mathrm{XZ}$ axis had a minimum of $-54.284 \mathrm{MPa}$ and a maximum of $35.008 \mathrm{MPa}$, with an average of $-5.3712 \mathrm{e}-002 \mathrm{MPa}$ (Figure $4 \mathrm{~g}$ ).

Deformation on the OX axis was between $-4.9018 \mathrm{e}-002 \mathrm{~mm}$ and $2.5572 \mathrm{e}-002 \mathrm{~mm}$, with an average of $-2.8357 \mathrm{e}-003 \mathrm{~mm}$ (Figure $4 \mathrm{~h}$ ). Deformation on the OY axis started from a minimum of $-4.935 \mathrm{e}-$ $002 \mathrm{~mm}$ and reached a maximum of $1.0814 \mathrm{e}-002 \mathrm{~mm}$, with an average value of $-6.612 \mathrm{e}-003 \mathrm{~mm}$ (Figure $4 \mathrm{i})$. The deformation on the $\mathrm{OZ}$ axis was between $-8.236 \mathrm{e}-003 \mathrm{~mm}$ and $6.2531 \mathrm{e}-002 \mathrm{~mm}$, with an average of $1.2931 \mathrm{e}-002 \mathrm{~mm}$ (Figure $4 \mathrm{j})$. 


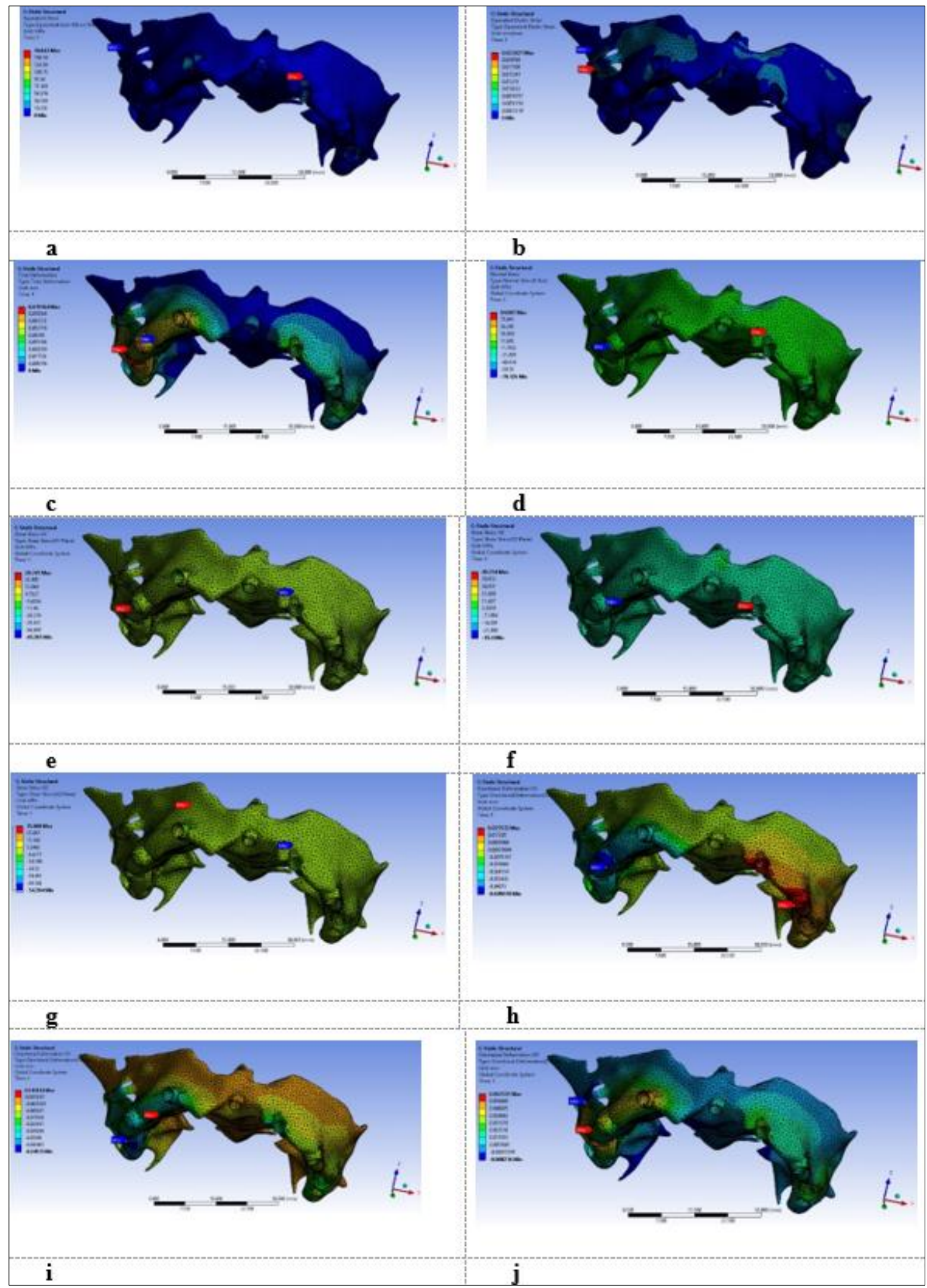

Figure 4. Simulations on the implants with large turns inserted at the maxillary level:

a) Equivalent pressure; b) Equivalent elastic relative deformation; c) Total deformation; d) Normal pressure; e) Shear stress on the XY axis; f)- Shear stress on the YZ axis; g) Shear stress on the XZ axis; h) Deformation on the OX direction; i) Deformation on the OY direction;

j) Deformation on the OZ direction 


\section{D) Implants with small turns inserted at the maxillary level}

The equivalent pressure varied between a minimum of $1.6955 \mathrm{e}-008 \mathrm{MPa}$ and a maximum of 152.72MPa, with an average of $6.582 \mathrm{MPa}$ (Figure 5a). Both minimum and maximum pressures, were recorded on the left side of the maxillary bone.

The equivalent elastic relative deformation ranged from $1.2817 \mathrm{e}-011 \mathrm{~mm} / \mathrm{mm}$ to $6.6081 \mathrm{e}-002$ $\mathrm{mm} / \mathrm{mm}$, with an average of $8.9815 \mathrm{e}-004 \mathrm{~mm} / \mathrm{mm}$ (Figure $5 \mathrm{~b}$ ).

The total deformation ranged from 0 , a value that was recorded at the palatal arch level and into the interincisive area, up to a maximum of $7.7897 \mathrm{e}-002 \mathrm{MPa}$ recorded in region 17 , with an average of 1.8153e-002 MPa (Figure 5c).

Normal pressure varied between $-102.23 \mathrm{MPa}$ and $31.778 \mathrm{MPa}$, with an average of $-0.1761 \mathrm{MPa}$ (Figure 5d).

The shear stress on the XY axis varied between $-29.485 \mathrm{MPa}$ and $37.224 \mathrm{MPa}$ (Figure 5e). The average value of shear stress was $-8.6255 \mathrm{e}-003 \mathrm{MPa}$. On the $\mathrm{YZ}$ axis, the shear stress varied between 68.034MPa and 38.272MPa (Figure 5f). On the XZ axis, the shear stress was between the limits -35.287 $\mathrm{MPa}$ and $43.761 \mathrm{MPa}$ (Figure 5g).

The deformation on the OX direction varied between $-4.8745 \mathrm{e}-002 \mathrm{~mm}$ and $2.575 \mathrm{e}-002 \mathrm{~mm}$ (Figure $5 \mathrm{~h}$ ). On the OY direction it varied between $-5.1879 \mathrm{e}-002 \mathrm{~mm}$ and $1.2377 \mathrm{e}-00 \mathrm{~mm}$ (Figure $5 \mathrm{i}$ ). On the OZ direction it was between $-1.5383 \mathrm{e}-002 \mathrm{~mm}$ and 5.9813e-002 $\mathrm{mm}$ (Figure 5j).

Studies have shown that, during the first year after implant insertion, an approximately $1 \mathrm{~mm}$ vertical bone loss will occur, followed frequently by an additional bone loss of $0.1 \mathrm{~mm}$ on each subsequent year. $[23,24]$

This marginal bone loss can be mainly caused by microbial accumulation around the implant and periimplantar tissues, or by inadequate mechanical stimuli [25].

Attempts have focused on increasing the diameter and / or length of the implants or modifying their design, in order to increase the contact area between the bone and the implant and to reduce stress into the periimplantar bone [26].

Some researchers [27] consider that the diameter of the implant is the most important factor that dictates the reduction of stresses and deformations in the periimplantar bone, while others [28] consider that the length of the implant has a greater impact on the distribution of stress in the periimplantar bone. On the other hand, it has been shown that neither the diameter of the implant, nor its length are as important as the surgical insertion technique, adequate primary stability and pre- and postoperative oral hygiene. [29]

Larger implants, in both diameter and length, has been shown to improve the distribution patterns of stresses and deformations; however, in many clinical situations, the alveolar bone does not have sufficient thickness or height to insert such implants. [26]

Finite element analysis (FEA) allows researchers to appreciate the pattern of stress and strain distribution in the periimplantar bone. [30]

Several clinical studies have shown that, on a long term, the success of small diameter implants is less frequent than standard diameter implants [31, 32]. A recent prospective study evaluated small diameter implants, that were monitored for 5 years, clinically and radiologically, and explained that the use of two $3 \mathrm{~mm}$ narrowing implants, is useful for stable marginal bone [33].

Other studies $[34,35]$ have shown that insertion of larger diameter implants is favorable for the longterm maintenance of the bone-implant interface in optimal conditions.

At equal demands on each implant, there are differences between the distribution of stresses and deformities into the maxillar and mandible, both because of the different characteristics of the two bones, mentioned in other studies [36], due to the fact that only 4 implants were possible on the mandible , while on the maxillar were possible 7 implants. Obviously, the positioning was imposed by the use of a real case with total edentation and different bone loss along the two arches. The 2 pterygoid implants, by the nature of their strongly inclined position, will determine demands on all 3 directions of the coordinate axes. 
Principled, the appearance of some request that change its sign - there are also areas with zero demand - it has the effect of producing a twisting of the element in which this pressure sign change appears, element named bone, which also has the weakest behavior from the mechanical point of view.

\section{Conclusions}

1) Regardless of the type of implant and regardless of the maxillary or mandibular area where the implants were virtually inserted, the critical areas in which extreme values are developed, are located into the bone at the neck-implant level and its apex level.

2) The tensions and deformations developed in our study does not present values that theoretically could endanger the osseointegration of the implants, but if they occur for long periods of time, they can induce fatigue of the bone substrate in the critical areas.

3) Implants with small turns induce lower stresses and deformations, compared to implants with large turns, regardless of the arch in which they were inserted on.

\section{References}

1CICCIU, M., et al, Materials, 11, 2018, p. 1512; doi:10.3390/ma11091512.

2.CERVINO, G., et al. Open Dent. J., 12, 2018, p. 219.

3.LAURITANO, F., et al, Minerva Stomatol., 65, 216, p. 353.

4.CICCIÙ, M., et al, Minerva Stomatol., 58, 2009, p. 9.

5.BRAMANTI, E., et al, Sci. World J., Volume 2017, Article ID 1029574, 7 pages, https://doi.org/10.1155/2017/1029574.

6.YASHWANT, A.V., et al. Journal of Clinical and Diagnostic Research 11.5, 2017: ZC17-ZC20.

7.KÜÇÜKKURT, S., et al. Computer Methods in Biomechanics and Biomedical Engineering 20.3, 2017, p. 284.

8.YAZICIOGLU, D., et al. Journal of Oral Implantology 42.1, 2016, p. 26.

9.SOTTO-MAIOR, B.S., et al. Computer Methods in Biomechanics and Biomedical Engineering 19.7, 2016, p. 699.

10.MARKOSE, J., et al. Journal of Contemporary Dental Practice 18.6, 2017, p. 510.

11.ARADYA, A., et al. Indian Journal of Dental Research 27.1, 2016, p. 78.

12.SESHA REDDY, M., et al. EC Dental Science 17.11, 2018, p. 1950.

13.OMORI, M., et al. International Journal of Implant Dentistry 1.1, 2015, p. 10.

14.DETOLLA, D.H., et al. Journal of Oral Implantology 26.2, 2016, p. 77.

15.COMANEANU, R.M., BARBU, H.M., VLASCEANU, D., TARCOLEA M., Key Engineering Materials, vol 583, 2014, p. 169.

16.ORMENISAN, A., TARCOLEA, M., SUCIU, M., GRIGORAS, R.I., BERESESCU, F.G., VLASCEANU, G., HANCU, V., COMANEANU, R.M., Mater. Plast., 52(3), 2015, 373.

17.COMAN, C., GHERGIC, D.L., PATROI, D.N., TARCOLEA, M., COMANEANU, R.M., BARBU, H.M., Mater. Plast., 53(1), 2016, 91.

18.COSARCA, A.S., GRIGORAS, R., HANCU, V., COMAN, C., COMANEANU, R.M., et al, Mater. Plast., 53(1), 2016, p. 135.

19.BERESESCU, G., ORMENISAN, A., COMANEANU, R.M., et al, Mater. Plast., 55(1), 2018, p. 42. 20.DRAGUS, L., TINU, A.S., COMAN, C., COMANEANU, R.M., GHERGIC, D.L., Rev. Chim. 69(9), $2018,2594$.

21.COMANEANU, R.M., BORDEA, L.E., PARASCHIV, V., BOTOACA, O., BECHIR, F., TARCOLEA, M., COMAN, C., TANASE, M., Rev. Chim., 70(1)1, 2019, 74.

22.ESPOSITO, M., HIRSCH, J.M., et al, Eur. J. Oral Sci. 106, 1998, p. 721.

23.COCS, J.F., ZARB, G.A., Int J Oral Maxillofac Implants., 2, no. 2, 1987, p. 91.

24.KIM, Y.T., LIM, G.H., et al, J Periodontal Implant Sci., 47, no. 4, 2017, p. 231.

25.PEIXOTO, C.D., ALMAS, K. et al, Odontostomatol Trop., 39, no. 153, 2016, p. 23.

26.UEDA, N., et al, J Prosthodont Res., 61, no. 3, 2017, p. 324. 
27.VAIRO, G., SANNINO, G., Comput Math Methods Med. Volume 2013, Article ID 250929, 15 pages, http://dx.doi.org/10.1155/2013/250929.

28.GUAN, H., et al, Int J Oral Maxillofac Implants., 24, no. 5, 2009, p. 866.

29.JAVED, F., ROMANOS, G.E., Clin Oral Investig., 19, no. 1, 2015, p.1-10.

30.SUGIURA, T., et al, Med Oral Patol Oral Cir Bucal., 20, no. 1, 2015, e66.

31.LEE, C.T., et al, Clin Oral Implants Res., 27, no. 10, 2016, p. 1251.

32.ZWEERS, J., et al, Clin Oral Implants Res., 26, no. 2, 2015, p. 149.

33.GALINDO-MORENO, P., et al. Clin Oral Implants Res., 28, no. 12, 2017, p. 1584.

34.OHYAMA, T., YASUDA, H., SHIBUYA, N., et al. J Oral Sci., 59, no. 2, 2017, p. 273.

35.JAFARIAN, M., et al, Dent Med Probl., 56, no. 1, 2019, p. 27.

36.CERVINO, G., et al. Open Dent J. 12, 2018, p. 219

Manuscript received: 16.12 .2019 